\title{
Inimigos da democracia: o Supremo Tribunal Federal
}

\author{
Bruno Ponich Ruzon ${ }^{1}$
}

\section{Resumo}

Analisa a forma de composição do Supremo Tribunal Federal. Questiona a adequação do artigo 101 da Constituição Federal à Democracia.

Palavras Chave: Supremo Tribunal Federal; Legitimidade; Composição; Democracia.

\section{Introdução}

A aferição de legitimidade de algum instituto ou instituição está sempre vinculada à adoção de uma postura crítica em relação ao ordenamento jurídico. Esta conduta de resistência pode inclusive incidir sobre normas inseridas no próprio texto constitucional. Não há qualquer óbice, pois no âmbito da legitimidade o jurista é livre, não tendo que se ater aos postulados da dogmática jurídica para apreciar um problema.

O problema tem espaço e tempo determinados, refletindo categoricamente a postura ideológica do jurista. Isto é algo muito importante, e que muitos ignoram. A ciência sempre tem início, principalmente nas Ciências Humanas, em uma decisão discricionária do pesquisador. Por isso, a pureza tanto defendida jamais pode ser alcançada, pois na gênese do pensamento científico há várias influências diversas da razão, que o contaminam.

Quando penso em analisar o Supremo Tribunal Federal (STF), estou sendo conduzido por vários sentimentos, medo, frustração, preocupação, mas talvez o crucial seja a consideração que possuo por este órgão da República. Sua missão é muito importante, está ali para resguardar a peça fundamental do sistema jurídico, a Constituição Federal. Para cumprir tão grande responsabilidade, grande é o poder que está nas mãos dos Ministros de nossa Corte Excelsa. Este poder está cada vez mais evidente, destaque-se a Emenda Constitucional 45/04, que incluiu no texto constitucional o artigo 103-A, trazendo a polêmica súmula vinculante. Digo evidente, pois o controle exercido pelo STF sempre foi enorme.

1 Advogado, bacharel em Direito pela Universidade Estadual de Londrina. 
Querendo ou não, são os Ministros do STF que concedem a última palavra acerca da interpretação das normas jurídicas. Como salienta o professor Alf Ross:

[...] é também um fato que mesmo supondo-se que o precedente não possua força obrigatória, os juízes da Europa continental [pode-se incluir aqui o Brasil] são influenciados, em grande medida, por decisões anteriores, e apenas esporádica e relutantemente se afastam da prática aceita. ${ }^{2}$

Poder. É isso que pretendemos dissecar. Nossos instrumentos são a razão, a dialética, os valores, e principalmente um discurso profano que não tem receio algum de questionar os dogmas estabelecidos.

\section{Delimitação do problema}

Com o advento da Constituição Federal de 1988, que trouxe expressamente o Estado Democrático de Direito à sociedade brasileira, antes afligida por um Estado controlado pelos militares, seria ingênuo acreditar que todas as estruturas seriam democratizadas como em um passe de mágica. Segundo o professor Lenio Streck:

Os legados da modernidade longe estão de serem realizados no Brasil. O Direito, como um desses principais legados - visto como instrumento de transformação social e não como obstáculo às mudanças sociais - formalmente encontrou guarida na Constituição de 1988. A forma desse veículo de acesso à igualdade prometida pela modernidade foi a instituição do Estado Democrático de Direito, que, porém, longe está de ser efetivado. ${ }^{3}$

É evidente que qualquer mudança no ordenamento jurídico só passa a ter efetividade perante o ambiente social após um determinado tempo. Ou seja, embora desde 1988 estivesse garantido o amplo acesso ao Poder Judiciário (art. 5ํ, XXXI, CF), o "boom" de ações só teve início alguns anos depois. Da mesma forma, o Ministério Público só tomou consciência (com todo o respeito, alguns de seus membros até hoje não a alcançaram) de sua vasta atribuição constitucional depois de certo tempo. Ademais, a necessidade de produção normativa infraconstitucional impossibilitaria a imediata efetivação do Estado Democrático de Direito.

ROSS, Alf. Direito e Justiça. Bauru (SP): EDIPRO, 2003 p. 115.

3 STRECK, Lenio Luiz. Hermenêutica jurídica $e(m)$ crise: uma exploração hermenêutica da construção do Direito. 4. ed. Porto Alegre: Livraria do Advogado, 2003. p. 213. 
Enfim, diante da nova ordem constitucional, todas as instituições da nossa sociedade deveriam adaptar-se ao modelo democrático. Universidades, escolas, hospitais, a polícia, os presídios, as famílias, as empresas etc teriam que se adequar à nova realidade jurídica. Em algumas delas percebemos alterações significativas, como é o caso da família, em outras se observa relutância em acolher a Democracia. Surge a dúvida, em qual grupo estaria o Supremo Tribunal Federal? Estaria ele mais próximo de um órgão revitalizado e democratizado, ou de um resquício do modelo abandonado?

Esta análise poderia abordar várias perspectivas, tantas quantas são as que decorrem do ideal democrático. Mas para o presente trabalho apenas uma foi escolhida. Trata-se da ocupação do poder. Ou seja, de como serão compostos os órgãos do Estado, no caso, se a forma de composição do Supremo Tribunal Federal está ou não em conformidade com a Democracia.

\section{Forma de composição do STF}

A Constituição Federal de 1988 foi bem clara ao estabelecer a forma de composição do mais alto Tribunal de nossa República:

Art. 101. O Supremo Tribunal Federal compõe-se de onze Ministros, escolhidos dentre cidadãos com mais de trinta e cinco anos, e menos de sessenta e cinco anos de idade, de notável saber jurídico e reputação ilibada.

Parágrafo único. Os Ministros do Supremo Tribunal Federal serão nomeados pelo Presidente da República, depois de aprovada a escolha pela maioria absoluta do Senado Federal.

Neste caso, o texto da norma não foge ao significado que a ela é dado. O cidadão é escolhido pelo Presidente da República e, após aprovação do Senado Federal, torna-se membro da Corte Excelsa.

Atualmente ${ }^{4}$, esta é a composição do STF:

- Sepúlveda Pertence - indicado por José Sarney;

- Celso de Mello - indicado por José Sarney;

- Marco Aurélio - indicado por Fernando Collor;

- Gilmar Mendes - indicado por Fernando Henrique Cardoso;

$4 \quad$ Artigo feito em 27 de junho de 2006. 
- Ellen Gracie - indicada por Fernando Henrique Cardoso;

- Carlos Ayres Britto - indicado por Luís Inácio Lula da Silva;

- Cezar Peluso - indicado por Luís Inácio Lula da Silva;

- Joaquim Barbosa - indicado por Luís Inácio Lula da Silva;

- Ricardo Lewandowski - indicado por Luís Inácio Lula da Silva;

- Cármen Lúcia Antunes Rocha - indicada por Luís Inácio Lula da Silva.

Observe-se que alguns Ministros foram indicados por Presidentes já não mais no poder, isto ocorre porque todos possuem as garantias da magistratura, entre elas a vitaliciedade (art. 95, I, CF). Daí porque normalmente um Ministro do Supremo Tribunal Federal só deixa o seu cargo por ato de vontade, pela aposentadoria compulsória (idade de

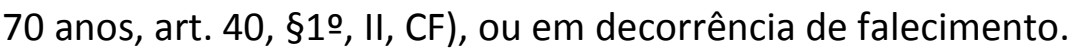

O atual Presidente da República ocupou 5 cadeiras das 11 existentes. Mesmo que não seja reeleito nas próximas eleições, sua interferência no Poder Judiciário, garantida constitucionalmente, se propagará por anos.

Esta é a realidade que possuímos, há aqueles que defendem o modelo atual, e os que propõem diversas alterações na forma de composição do Supremo Tribunal Federal.

\section{0 discurso conservadorista}

Para justificar a norma do artigo 101 da Constituição Federal utiliza-se a teoria dos freios e contra pesos. Afirma-se que apenas através dela é possível resguardar a harmonia entre os três poderes. Ela legitima a interferência recíproca dos poderes. Assim, o poder seria controlado pelo próprio poder. O Presidente fiscalizaria o processo legislativo através do veto, o Poder Legislativo controlaria o Poder Executivo pelo Tribunal de Contas, o Poder Judiciário controlaria a Administração Pública através de seus julgamentos, e assim por diante.

Está é uma interessante teoria que, em nossa República, foi distorcida para justificar a concentração do poder nas mãos do Executivo. Depurando analiticamente a Constituição Federal é muito fácil constatar que não há harmonia alguma entre os poderes, mas sim um total controle do Poder Executivo sob os demais. Isto é um problema, pois escolhemos a Democracia, e a ela se opõe totalmente à idéia de concentração de poder. 


\section{Parcialidade dos Ministros}

Muitos pensadores entendem que a atual forma de composição do Supremo Tribunal Federal seria prejudicial à República por corromper a imparcialidade dos Ministros nomeados. Com base neste fundamento pedem a reformulação do artigo 101 da Constituição Federal. Defendem que de alguma forma, até mesmo inconsciente, as decisões acabariam por favorecer aos interesses do Governo (entenda-se, não só ao interesse do Presidente, mas de todo o grupo político que o sustenta), restando desse modo viciadas. Isso, obviamente, se o Governo tivesse a chance de nomear algum Ministro, já que, por força da vitaliciedade, é possível que um Presidente termine o seu mandato sem exercer tal prerrogativa. De qualquer forma, sempre haveria uma ligação incômoda entre o Ministro nomeado e o principal morador do Planalto da Alvorada.

Esta tese já possui respaldo histórico, havendo vários casos em que a parcialidade do Ministro restou evidenciada. Apenas para ilustrar, destaque-se o caso do exministro do STF, Nelson Jobim (indicado por Fernando Henrique Cardoso), que com o intuito de resguardar o ex-ministro da Ciência e Tecnologia Ronaldo Sardenberg (do governo tucano), que utilizou aviões públicos para fins particulares, acolheu na Reclamação 2138 a débil tese de que a Lei de Improbidade Administrativa (Lei 8.429/92) não seria aplicável aos agentes políticos, pois estes só responderiam por crime de responsabilidade.

No que pese este e outros incidentes históricos, parece-me que o comprometimento da imparcialidade dos Ministros não seja o principal problema do artigo 101 da Constituição Federal. Afinal, eles possuem as garantias da magistratura (art. 95, CF): vitaliciedade, inamovibilidade (o que de nada serve no STF) e irredutibilidade. Por isso, querendo, são livres para decidir conforme sua convicção. Com o devido respeito, esta tese da parcialidade dos Ministros não merece prosperar. Que eles não sejam neutros todos já sabem, mas não porque esta seja uma característica deles. A ausência de neutralidade é algo inerente a qualquer julgador, pois são seres humanos inaptos a livrarem-se de certos preconceitos e valores enraizados em seus corações. É outro o aspecto que compromete a legitimidade do Supremo Tribunal Federal. 


\section{Ofensa à Democracia}

É triste ter que informá-los que o Supremo Tribunal Federal está no grupo das instituições que ainda não se adaptaram ao modelo democrático. Pior, enquanto algumas já possuem formalmente uma estrutura democrática, o Supremo Tribunal Federal ainda está constitucionalmente antidemocrático. Ressalte-se, não podemos afirmar que o artigo 101 da Constituição Federal seja inconstitucional. Por mais que alguns juristas acreditem nessa possibilidade, nossa postura lógica e positivista não permite a afirmação de que na Constituição Federal existam normas inconstitucionais. Mas ele é totalmente ilegítimo pois contraria valor supremo escolhido pelos brasileiros, qual seja, a Democracia.

Alguns dos postulados da Democracia são cabalmente ofendidos pela Constituição Federal, artigo 101. Ocorre que:

\footnotetext{
Um dos elementos substanciais da democracia é a prevalência da vontade do povo sobre a de qualquer indivíduo ou grupo. Quando um governo, ainda que bem intencionado e eficiente, faz com que sua vontade se coloque acima de qualquer outra, não existe democracia. Democracia implica autogoverno, e exige que os próprios governados decidam sobre as diretrizes políticas fundamentais do Estado. ${ }^{5}$
}

Em nossa Democracia Semi-Direta, em que a participação no processo legislativo é destinada apenas aos representantes escolhidos através do voto, e em raras exceções exercida pelo próprio povo, através do plebiscito, referendo ou iniciativa de lei, é a Câmara de Deputados que representa os brasileiros. O Senado Federal existe para representar os diversos Estados-membros. Surge a pergunta: Em qual momento a Câmara de Deputados interfere na escolha dos Ministros do Supremo Tribunal Federal? Não há resposta à questão, pois não há qualquer participação da Câmara na composição do STF. Apenas para ilustrar o absurdo do atual modelo, destaque-se o que dizia a Constituição outorgada de 1967:

Art. 113. O Supremo Tribunal Federal, com sede, na Capital da União e jurisdição em todo o território nacional, compõe-se de dezesseis Ministros.

$\S 1$ o - Os Ministros serão nomeados pelo Presidente da República, depois de aprovada a escolha pelo Senado Federal, dentre brasileiros, natos, maiores de trinta e cinco anos, de notável saber jurídico e reputação ilibada.

$\S 2$ - $[\ldots]$

5 DALLARI, Dalmo de Abreu. Elementos de teoria geral do Estado. São Paulo: Saraiva, 2001. p. 304. 
Não só a Câmara não participa desta seleção, como, de fato, a palavra final é sempre a do Presidente da República. Pressuponha-se que uma certa indicação feita pelo Presidente não seja aprovada pelo Senado Federal, conforme garante o sistema atualmente vigente. Pois bem, competirá ao Presidente indicar outro nome, e assim por diante até conseguir uma aprovação. Observe que sempre, inevitavelmente, o Ministro escolhido terá a aprovação do Presidente da República. No atual procedimento o poder concentra-se inteiramente nas mãos do Poder Executivo. Ficamos totalmente reféns, mesmo que toda a comunidade jurídica deseje ver determinada pessoa nas cadeiras do Supremo Tribunal Federal, nada conseguiremos sem a "benção" do Presidente da República. Isto está errado, isto fere mortalmente a Democracia. A Assembléia Constituinte teve a oportunidade de equilibrar a balança do poder no Brasil, e não o fez. Não é a primeira vez que atrás de uma grande reforma vem escondida a manutenção do status quo. Veja-se o que Ferdinand Lassale disse em 1862 sobre o que deveria ter sido feito na Constituição Prussiana de 1848:

Deslocar os fatores reais e efetivos do poder dentro do país, imiscuir-se [intrometer] no Poder Executivo, imiscuir-se [intrometer] nele tanto e de tal modo, balança-lo e transformá-lo de tal maneira que se incapacitasse para nunca mais se colocar como soberano diante da nação $[. . .]^{6}$

Isso não foi possível na Prússia do século XIX, tampouco no Brasil do final do século XX. A Assembléia Constituinte de 1988 melhorou muito o nosso sistema jurídico, há mérito nisso, mas ao mesmo tempo manteve várias estruturas arcaicas e antidemocráticas, dentre elas o atual Supremo Tribunal Federal.

Muitos dizem que é o momento de lutar por uma Democracia material, porém, acredito que ainda há vários dispositivos constitucionais, ou seja, aspectos formais que impedem a concretização da Democracia. A atual forma de composição do Supremo Tribunal Federal é um deles. Enquanto vemos Peter Häberle ${ }^{7}$ pregando a sociedade aberta dos intérpretes da Constituição, em nossa República temos ainda que nos levantar contra os resquícios de um Estado Ditatorial. Será que nestes mais de 15 anos de vigência da atual Constituição Federal ninguém percebeu que a escolha dos Ministros do STF estava errada?

LASSALE, Ferdinand. O que é uma Constituição? Belo Horizonte: Editora Líder, 2004. p.67.

HÄBERLE, Peter. Hermenêutica Constitucional. Porto Alegre: Sergio Antonio Fabris Editor: 2002 
São 15 anos aprisionando a Democracia, não a deixando alcançar nossa Suprema Corte Constitucional!

\section{Conclusão}

Diante do exposto, comprovado está que em nosso texto constitucional há dispositivo que se opõe frontalmente ao valor Democracia, trata-se do artigo 101, que disciplina a forma de composição do Supremo Tribunal Federal.

Assim, face ao problema, é essencial a intervenção do Poder Constituinte Derivado para que, através de uma Emenda Constitucional, estabeleça-se um novo modelo, que permita a participação da Câmara de Deputados, bem como do Poder Judiciário, do Ministério Público, da OAB etc, na formação do Supremo Tribunal Federal.

\section{Referências}

DALLARI, Dalmo de Abreu. Elementos de teoria geral do Estado. São Paulo: Saraiva, 2001.

HÄBERLE, Peter. Hermenêutica Constitucional. Porto Alegre: Sergio Antonio Fabris: 2002.

LASSALE, Ferdinand. O que é uma Constituição? Belo Horizonte: Líder, 2004.

ROSS, Alf. Direito e Justiça. Bauru (SP): EDIPRO, 2003.

STRECK, Lenio Luiz. Hermenêutica jurídica $e(m)$ crise: uma exploração hermenêutica da construção do Direito. 4. ed. Porto Alegre: Livraria do Advogado, 2003. 